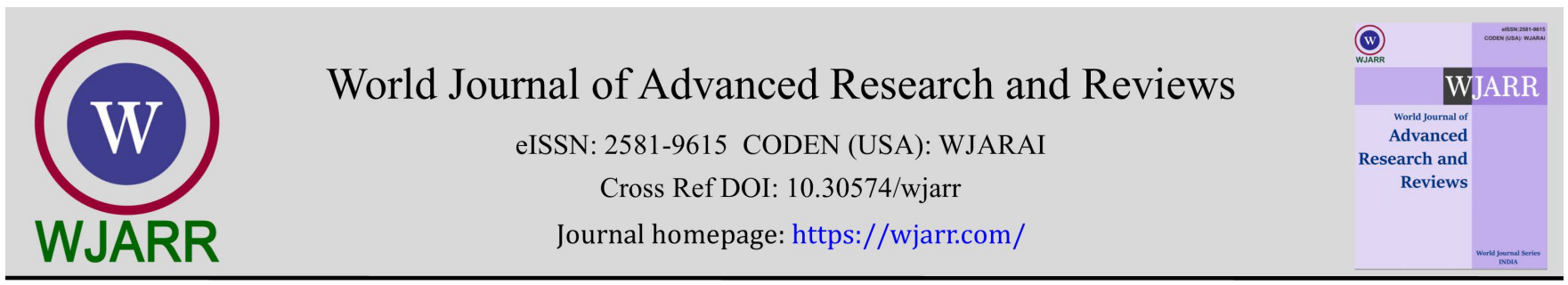

(RESEARCH ARTiClE)

\title{
Effect of partnership strategy on competitive advantage mediated by market area and moderated by health service innovation: Hospital case in Ambon, Indonesia
}

\author{
Hisnindarsyah * \\ Hang Tuah University, Surabaya, Indonesia. \\ World Journal of Advanced Research and Reviews, 2022, 13(02), 377-388 \\ Publication history: Received on 10 January 2022; revised on 14 February 2022; accepted on 16 February 2022
}

Article DOI: https://doi.org/10.30574/wjarr.2022.13.2.0154

\begin{abstract}
The purpose of this studies to take a observe the Effect of Partnership Strategy on Competitive Advantage mediated through manner of Market Area and moderated through manner of Health Service Innovation. This study is quantitative research with a case have a take a observe on fifteen hospitals and forty health centres in Ambon City, Indonesia. The data processed the usage of the Smart PLS -3 software program for Structural Equation Modelling. This have a take a observe proposes a version of partnership strategy variables on competitive advantage the usage of the market area as a mediating variable and health service innovation as a moderating variable that has now not been extensively studied. The results show that the partnership strategy has a direct effect on competitive advantage. The partnership strategy has a direct effect on the market area, but the market area cannot mediate the relationship between the partnership strategy and competitive advantage. Health service innovation has a direct effect on competitive advantage, but health service innovation cannot moderate relationship between partnership strategy and competitive advantage and cannot moderate relationship between market area and competitive advantage. While the market area has no direct significant effect on competitive advantage.
\end{abstract}

Keywords: Partnership Strategy; Competitive Advantage; Market Area; Health Service Innovation; Hospital; Health Centre

\section{Introduction}

Basically, public services cover a very wide range of aspects of life. In the life of the country, the government is tasked with providing the various public services that the community needs, from services in the form of regulations and other services to meet the needs of the community such as education and health. Several public reform movements in developed countries in the early 1990s were stimulated by public pressure on the need to improve the quality of public services provided by governments.

The health system is an important part of improving public health. Also, keep in mind that the success of a healthcare system depends on the various components that exist in the healthcare service. A system is made up of subsystem inputs, processes, outputs, influences, feedback, and environments, which are interconnected and influence.

Hospitals, on the other hand, are one of the public services sectors that are obliged to provide superior services to communities that use health services. However, although the government has endeavored to improve the quality of public services by various means, the current state of public services still does not fully meet the needs and expectations of the people.

\footnotetext{
${ }^{*}$ Corresponding author: Hisnindarsyah

Hang Tuah University, Surabaya, Indonesia.

Copyright $(2022$ Author(s) retain the copyright of this article. This article is published under the terms of the Creative Commons Attribution Liscense 4.0.
} 
There are two types of services from the hospital as a health service subsystem, namely providing health services and administration. Where health services include medical services, medical rehabilitation, medical support and nursing services. The four types of services are carried out by the Technical Service Unit (UPT), such as the Emergency Unit, Outpatient Unit, Inpatient Unit, Blood Transfusion Unit, Pharmacy Unit, and so on. Administrative services include all types of administrative services, including financial administration whose main function is to assist the smooth implementation of health services.

Currently, Rumkital dr. F.X. Suhardjo, has collaborated/partnered with the Maluku Provincial Health Office to support various archipelagic health-oriented activities such as Sailing Medical Service and socialization of emergency problems in diving and hyperbaric oxygen therapy. This activity is an implication of the synergy between the Indonesian Navy, especially Rumkital dr. F.X. Suhardjo with the Maluku Provincial Health Office, to support the vision and mission of archipelagic health that goes hand in hand with the concept of diving and hyperbaric health. Diving and hyperbaric health is what Rumkital dr. F.X. Suhardjo, to compete in the era of globalization, in providing health services for the people of Maluku Province.

Today, superior customer service is one of the characteristics of a high-performance business. Therefore, a company must create and maintain a service climate so that employees within the company can effectively provide excellent service. Service strategy is a series of marketing service activities that increase company profits by Lovelock and Wirtzin $[1$, p. 135]. A successful service strategy can create a sustainable competitive advantage, which competitors cannot easily imitate by Bharadwaj et al., in [1]. The service concept combines the available service capacity, delivery service channels, as well as the processes and methods available to provide services to customers [2]. Besides that, it is also necessary to innovate health services involving health workers, superior health facilities, the Sailing Medical Service program, the Customer Care Program, price adjustments including the location of Rumkital dr. F. X. Suhardjo, so that it can be used to compete with other hospitals.

According to Urabe [3], innovation is an important thing in achieving competitive advantage. Without innovation, companies will die. Companies that innovate continuously will be able to dominate the market, with new product creations, models and appearances. In the end, the innovation strategy will bring out the uniqueness of the product that is difficult for competitors to imitate.

Data based on observations in the field, it can be seen that the number of clients has decreased where in 2015 there were 3237 patients who came for treatment at Rumkital dr. F.X. Suhardjo and in 2016 there was a very drastic decline of 1649 clients, then in 2017 it continued to decline to 1562 clients. Meanwhile, in 2018 there was an increase in 1731 clients.

In addition to the opinion that partnership strategies and environmental changes can help companies achieve competitive advantage, there are several other opinions that say that product innovation is the key to success in achieving competitive advantage.

\section{Problem Statement}

Based on several research findings that show different results on the direct relationship of partnership strategy to competitive advantage, it raises the question of whether partnership strategy to competitive advantage is inseparable from the mediating variable? It is possible that the relationship between the partnership strategy to competitive advantage is not a direct relationship but an indirect relationship through the market area, while service innovation as a moderator allows influencing the strength of the partnership strategy to competitive advantage. Including the market area as a mediation and service innovation as a moderator is considered important considering that research on partnership strategies for competitive advantage rarely includes market area and service innovation variables in the relationship model.

This study uses a partnership strategy as an independent variable that affect competitive advantage as the dependent variable mediated by the market area and moderated by health service innovation. The problems studied can then be formulated in the form of several questions:

- Does the Partnership Strategy have an effect on Competitive Advantage?

- Does the Partnership Strategy have an effect on Competitive Advantage through the Market Area?

- Can Health Service Innovation moderate the Partnership Strategy and Market place on Competitive Advantage? 


\section{Literature Review}

This study is based on several controversies theoretical and empirical findings from various studies of strategic management and inter-organizational marketing cooperation. The controversy from the results of the study can be seen as follows:

Differences in views, implementation and results of studies on partnership strategies in relation to competitive advantage. According to Poole and Ven [4], said that the partnership strategy is the right collaboration to equalize themselves, especially when companies are looking for unique and superior resources. This is supported by the opinion of Bleeke and Ernestin [5] which states that the formation of strategic alliances and cooperation is primarily motivated to gain competitive advantage in the market. Meanwhile Hamel, G et al, in [5] suggest that strategic alliances are also the answer for many companies trying to gain competitive advantage.

In contrast to the opinion of several researchers above who argued that the importance of a partnership strategy to achieve a company's competitive advantage. Other studies say that the competitive advantage of a business is more influenced by the ability of the management to manage the environment, not on its strategic alliance. Brown and Karagozoglu in [5] suggest proactive corporate environmental management as a corporate strategy to be able to create competitive advantage because consumer demands are increasingly sensitive to the importance of environmental factors as a supporter of human survival. Research conducted by Chavan in [5], suggests that the application of good environmental management will help companies gain competitive advantage and not only in their strategic alliances. Based on the description of these studies, it is concluded that there are still differences in the meaning, use, and treatment of partnership strategies. Therefore, this study is intended to clarify the partnership strategy in relation to competitive advantage.

In addition to the opinion that partnership strategies and environmental changes can help companies achieve competitive advantage, there are several other opinions that say that product innovation is the key to success in achieving competitive advantage. Korth's research in [5] suggests that companies can achieve competitive advantage through continuous innovation. In his writing, Prasetya [5] identifies four types of innovation, namely: products and services, manufacturing processes, materials and invasions in business practices. Companies need to always try to improve their capabilities and innovation activities. In rapidly changing environmental conditions, competitive advantage is determined by creativity and innovation that can satisfy customer desires better than competitors.

Another opinion was also expressed by Campbell, et. al., [6] in his research that an industry consists of a number of factories that have a sequential market area to maximize profits and profit is expected depending on the cost of a particular location. Thus, each industry needs to determine its geographic concentration index for its competitive advantage. The market area determines the company's competitiveness in process capacity, flexibility and cost, customer contact and corporate image.

The relationships between the variables under investigation are described in the conceptual framework of investigation, as shown in the following figure.

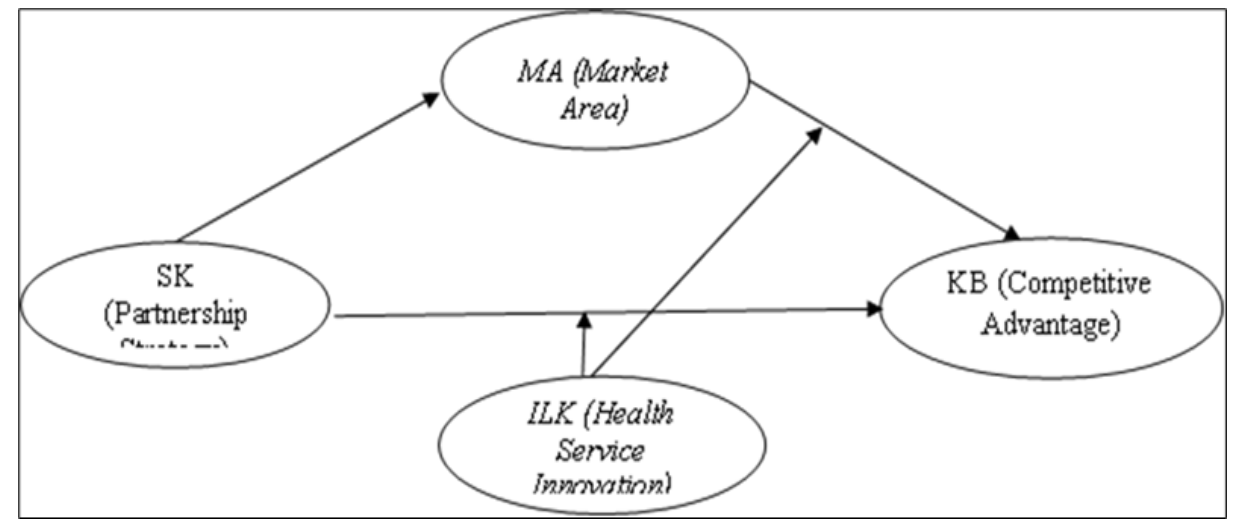

Figure 1 Research Conceptual Framework 
Hypothesis is a temporary conclusion or about the influence between two or more variables, the conclusion or temporary answer must be tested for truth by conducting research. Based on the description above, the results of previous research, the framework of the thought process and the conceptual framework of the research that has been stated previously, the research hypothesis can be formulated as follows:

\subsection{Impact of Partnership Strategy on Competitive Advantage}

The implementation of a good partnership strategy in a company will produce a competitive advantage. The formation of a partnership strategy is motivated by a competitive advantage in the market [7].

The strategic partnership has a significant positive effect on competitive advantage. These results mean that the implementation of a good strategic partnership in a company will produce a competitive advantage. In accordance with the thinking of Y. Doz, et al. [8] which states that strategic partnerships can be described as the key to competitive success. The formation of strategic partnerships is motivated to gain a competitive advantage in the market [9]. Strategic partnerships are the answer for many companies who are trying to gain a competitive advantage [8].

Research on the effect of partnership strategies on competitive advantage has been carried out by previous researchers including Ariefiantoro [10], Winata [11], Prasetya et al [5], which resulted in a partnership strategy having a positive effect on competitive advantage. Based on the description above, the hypothesis is formulated as follows:

\section{- H1: Partnership Strategy Affects Competitive Advantage.}

\subsection{Impact of Partnership Strategy on Competitive Advantage through Market Area}

A partnership approach is an approach that may triumph over aggressive pressures in an industry, an organization is wanted for an international commercial enterprise environment, wherein an organization wishes to have an intensive community with different commercial enterprise players [12].

The way an organization relates to its market is one of the main aspects of competitive strategy. The idea of a market as a place where buyers and sellers meet. Market products are products for which organizations compete for product sales; Resource markets are where organizations compete for inputs for their resources.

Marketing strategy is seen as a general statement of direction or guidance in selecting target markets and designing and implementing a marketing mix [13], three main aspects of strategy covered are: 1) where to compete? determination of the market chosen by the company; 2) on what basis to compete? development of products and services; and 3) when to compete? timing of market entry and market development activities. According to Cravens [14], competitive market situation analysis is the first step in designing a new strategy or reviewing an existing strategy. This situation analysis is carried out after the strategy has been implied to determine the necessary strategic changes. Situation assessment is usually defining and analyzing the market, and competitor analysis.

The market area has many strategic impacts because the market location determines the company's competitiveness in capacity, process, flexibility, and cost, as well as a good quality work environment can help organizations achieve a strategy that supports a complex competitive advantage. The aim of the market area strategy is to build an economical market area that meets the needs of the competition. The market area according to Kotler [15] is an association in order that a product occupies a clear, awesome and proper vicinity relative to competitors' merchandise within side the minds of goal consumers.

According to Weber [16], broadly speaking, location theory can be categorized into 3 main groups, namely: 1) Least Cost Theory, which emphasizes analysis on production aspects and ignores market and demand elements. 2) Market area theory, which emphasizes demand is more important in terms of location selection. If the demand for an item is price elastic, it is estimated that there will be various effects on the choice of the company's location. In addition, the existence of an element of spatial competition among producers also determines the company's behaviour in choosing a location. 3) Bid Rent Theory, the choice of location for industrial companies is largely determined by the ability of the company concerned to pay land rent. In this case, the position of Rumkital dr. F.X. Suhardjo, which is located in the middle of Ambon Island and on the coast, has a strategic impact for easier access to services than other hospitals.

Hospitals and Community Health Centers in Ambon City and Maluku Islands are the market areas for research related to this partnership. Through the ability to approach and provide services according to their needs, it is hoped that there will be satisfaction so that there will be efforts to maintain relations between each party, so as to increase the 
competitive advantage of Rumkital dr. F.X. Suhardjo. This is in accordance with the opinion of Mintzberg [17], that the position of producers related to location selection and a predetermined target market has an effect on demand.

Based on the description above, the results of previous research, the framework of the thought process and the conceptual framework of the research that has been stated previously, the research hypothesis can be formulated, as follows:

- H2: Partnership strategy affects competitive advantage through the market area.

\subsection{Health Service Innovation moderate the Partnership Strategy and Market Area on Competitive Advantage}

Indriani [18] states that: The role of partnership strategy and product development has a significant influence so that it is expected to always create innovations for the company's products and make continuous improvements in order to survive in today's competitive situation.

According to Ferdinand [19] that competitive advantage is something that every company is looking for, even every product in the market it enters. This is important because when a company enters a highly competitive market, the short-term and long-term success is determined by the company's ability. to build a solid base on sustainable advantage over its competitors in the target market. Therefore, as an effort to face this global competition, a cooperative strategy is needed which is called a partnership strategy. This partnership strategy is an effort to build partnerships with governments, companies and organizations that are able to bring in new resources and bring credibility to our company.

Research Dröge, et al [20]observed that the product may be used as a supply of aggressive advantage. Companies which can be capable of layout merchandise consistent with consumer dreams can be capable of live to tell the tale within side the midst of worldwide competition. So, the strategy by considering products that can be used as a superior is an effective strategy in facing competition, especially for products that are not owned by other competitors. In addition, with the product factor that is only owned by our company, the market area will be controlled. On the other hand, product development efforts to remain acceptable and survive to consumers can be carried out with superior product innovation.

It has been shown that market share among major competitors is often very stable over a long period of time by Monczka et al, [21] and this can be used as a critique of the product cycle concept. Companies in service and process innovation are increasingly important for competition in many industries. Some research shows that companies that invest more in research and development and create more innovation tend to perform better in a variety of industries. Service innovation tends to be more important in emerging and developing industries, process innovation in mature industries.

Based on the above explanation, the results of previous studies, the framework of the thinking process, and the conceptual framework of the studies mentioned above, the research hypothesis can be formulated as follows.

H3: Health Service Innovation can moderate the Partnership Strategy and Market Area on Competitive Advantage

\section{Methodology}

The type of research used is quantitative where the data obtained will be analyzed statistically. The research data presented are within side the shape of numbers and analysed the usage of statistics according to concrete and systematic scientific rules [22]. The method used in this research is a survey with a Likert scale questionnaire as the research instrument. The population \& research sample are as explanation below.

Considering that the population in this study is heterogeneous in terms of partnership and there are differences in distance between the location of Rumkital dr. F.X. Suhardjo Lantamal IX Ambon and hospitals and health centres throughout Maluku Province, before taking the sample, the researcher determined the following sample criteria:

- Hospitals and health centres in collaboration with Rumkital dr. F.X. Suhardjo Lantamal IX Ambon through a cooperation agreement.

- The distance between the location of the Hospital and health centres with Rumkital dr. F.X. Suhardjo Lantamal IX Ambon is not more than $50 \mathrm{~km}$.

After the above population is selected by these criteria, a population of 15 hospitals and 40 health centres is obtained, which is hereinafter referred to as the target population. 
Considering that the research population consisted of 15 hospitals and 40 health centres, with this relatively small number, researchers were able to access the required data. Therefore, all participants of the populace may be used as studies samples. So that the sampling method used is a saturated sampling method. This is according with the opinion of Sugiyono [23] which says that saturated sampling is a sampling technique when all members of the population are used as samples. In the selection of respondents, it is determined by people who reflect the organization, in this case represented by the head or head and chair of the medical committee at the hospital, as well as the head and secretary at the health centres. So as to suffice as many as 2 (two) people in each organizational unit.

Understanding the operation of variables is a research item that shows how to measure variables and is a kind of implementation guide for measuring variables. This study consists of four variables to investigate, namely the independent variable: Partnership Strategy (SK) - 8 indicators, the mediation variable: Market Area (MA)- 6 indicators, the moderation variable: Health Service Innovation (ILK)- 8 indicators and the dependent variable: Competitive Advantage (KB)- 6 indicators. The collected data is processed using the Structural Equation model with the smartPLS 3 program.

\section{Results and discussion}

\subsection{Evaluation of Measurement}

\subsubsection{Validity Test}

If the load factor of the indicator on the expected variable is more than 0.7 , the indicator can be declared valid. The Smart PLS-3 output of the load factor offers the following assessment results:

Table 1 Result for Outer Loading

\begin{tabular}{|l|l|l|l|l|l|l|}
\hline & ILK & KB & MA & ME 1 & ME 2 & SK \\
\hline ILK1 & 0.866 & & & & & \\
\hline ILK2 & 0.846 & & & & & \\
\hline ILK3 & 0.781 & & & & & \\
\hline ILK4 & 0.822 & & & & & \\
\hline ILK5 & 0.819 & & & & & \\
\hline ILK6 & 0.877 & & & & & \\
\hline ILK7 & 0.777 & & & & & \\
\hline ILK8 & 0.849 & & & & & \\
\hline KB1 & & 0.770 & & & & \\
\hline KB2 & & 0.840 & & & & \\
\hline KB3 & & 0.776 & & & & \\
\hline KB4 & & 0.815 & & & & \\
\hline KB5 & & 0.832 & & & & \\
\hline KB6 & & 0.797 & & & & \\
\hline MA * ILK & & & & 1.387 & & \\
\hline MA1 & & & 0.875 & & & \\
\hline MA2 & & & 0.875 & & & \\
\hline MA3 & & & 0.818 & & & \\
\hline MA4 & & & 0.753 & & & \\
\hline MA5 & & & 0.892 & & & \\
\hline
\end{tabular}




\begin{tabular}{|l|l|l|l|l|l|l|}
\hline MA6 & & & 0.895 & & & \\
\hline SK * ILK & & & & & 1.362 & \\
\hline SK1 & & & & & & 0.867 \\
\hline SK2 & & & & & & 0.809 \\
\hline SK3 & & & & & & 0.789 \\
\hline SK4 & & & & & & 0.864 \\
\hline SK5 & & & & & & 0.823 \\
\hline SK6 & & & & & & 0.836 \\
\hline SK7 & & & & & & 0.794 \\
\hline SK8 & & & & & & 0.798 \\
\hline
\end{tabular}

Reflection indicators also need to be forced to crossload for discriminatory validity, as follows:

Table 2 Result for Cross Loading

\begin{tabular}{|l|l|l|l|l|l|l|}
\hline & ILK & KB & MA & ME 1 & ME 2 & SK \\
\hline ILK1 & 0.866 & 0.367 & 0.221 & -0.097 & -0.079 & 0.512 \\
\hline ILK2 & 0.846 & 0.397 & 0.263 & -0.136 & -0.083 & 0.544 \\
\hline ILK3 & 0.781 & 0.369 & 0.184 & -0.192 & -0.159 & 0.465 \\
\hline ILK4 & 0.822 & 0.427 & 0.255 & -0.091 & -0.145 & 0.617 \\
\hline ILK5 & 0.819 & 0.383 & 0.197 & -0.104 & -0.143 & 0.528 \\
\hline ILK6 & 0.877 & 0.431 & 0.230 & -0.088 & -0.077 & 0.615 \\
\hline ILK7 & 0.777 & 0.409 & 0.206 & -0.113 & -0.030 & 0.466 \\
\hline ILK8 & 0.849 & 0.409 & 0.202 & -0.125 & -0.117 & 0.552 \\
\hline KB1 & 0.442 & 0.770 & 0.170 & -0.171 & 0.008 & 0.413 \\
\hline KB2 & 0.379 & 0.840 & 0.253 & -0.134 & -0.017 & 0.434 \\
\hline KB3 & 0.499 & 0.776 & 0.136 & -0.155 & -0.061 & 0.430 \\
\hline KB4 & 0.378 & 0.815 & 0.319 & -0.062 & -0.010 & 0.451 \\
\hline KB5 & 0.353 & 0.832 & 0.394 & -0.188 & -0.114 & 0.512 \\
\hline KB6 & 0.298 & 0.797 & 0.474 & -0.166 & -0.080 & 0.456 \\
\hline MA * ILK & -0.142 & -0.182 & -0.456 & 1.000 & 0.459 & -0.087 \\
\hline MA1 & 0.222 & 0.248 & 0.875 & -0.340 & -0.108 & 0.332 \\
\hline MA2 & 0.249 & 0.328 & 0.875 & -0.398 & -0.030 & 0.332 \\
\hline MA3 & 0.139 & 0.279 & 0.818 & -0.434 & -0.118 & 0.250 \\
\hline MA4 & 0.196 & 0.330 & 0.753 & -0.425 & -0.104 & 0.301 \\
\hline MA5 & 0.279 & 0.343 & 0.892 & -0.367 & -0.085 & 0.406 \\
\hline MA6 & 0.249 & 0.346 & 0.895 & -0.381 & -0.023 & 0.342 \\
\hline SK * ILK & -0.125 & -0.060 & -0.088 & 0.459 & 1.000 & -0.094 \\
\hline SK1 & 0.569 & 0.501 & 0.341 & -0.106 & -0.147 & 0.867 \\
\hline
\end{tabular}




\begin{tabular}{|l|l|l|l|l|l|l|}
\hline SK2 & 0.520 & 0.407 & 0.340 & -0.112 & -0.126 & 0.809 \\
\hline SK3 & 0.448 & 0.444 & 0.297 & -0.082 & -0.096 & 0.789 \\
\hline SK4 & 0.628 & 0.450 & 0.329 & 0.017 & 0.030 & 0.864 \\
\hline SK5 & 0.494 & 0.441 & 0.268 & -0.067 & -0.099 & 0.823 \\
\hline SK6 & 0.537 & 0.477 & 0.366 & -0.049 & 0.000 & 0.836 \\
\hline SK7 & 0.529 & 0.453 & 0.339 & -0.115 & -0.057 & 0.794 \\
\hline SK8 & 0.547 & 0.506 & 0.271 & -0.060 & -0.129 & 0.798 \\
\hline
\end{tabular}

The desk above indicates that the load factor offers a value above the recommended value of 0.7 .

The reflectance validation makes use of the correlation among the object rating and the variable rating. If different signs of the equal variable change (or are eliminated from the model), measurements the usage of the mirrored image indicator display modifications within side the variable. The desk above suggests that the load factor value is better than the recommended value of 0.7. The minimal price for the MA4 index is 0.753 . This method that the signs used on this look at may be declared legitimate or have performed the effectiveness of convergence. The following discern is a load factor chart for every indicator of this studies model.

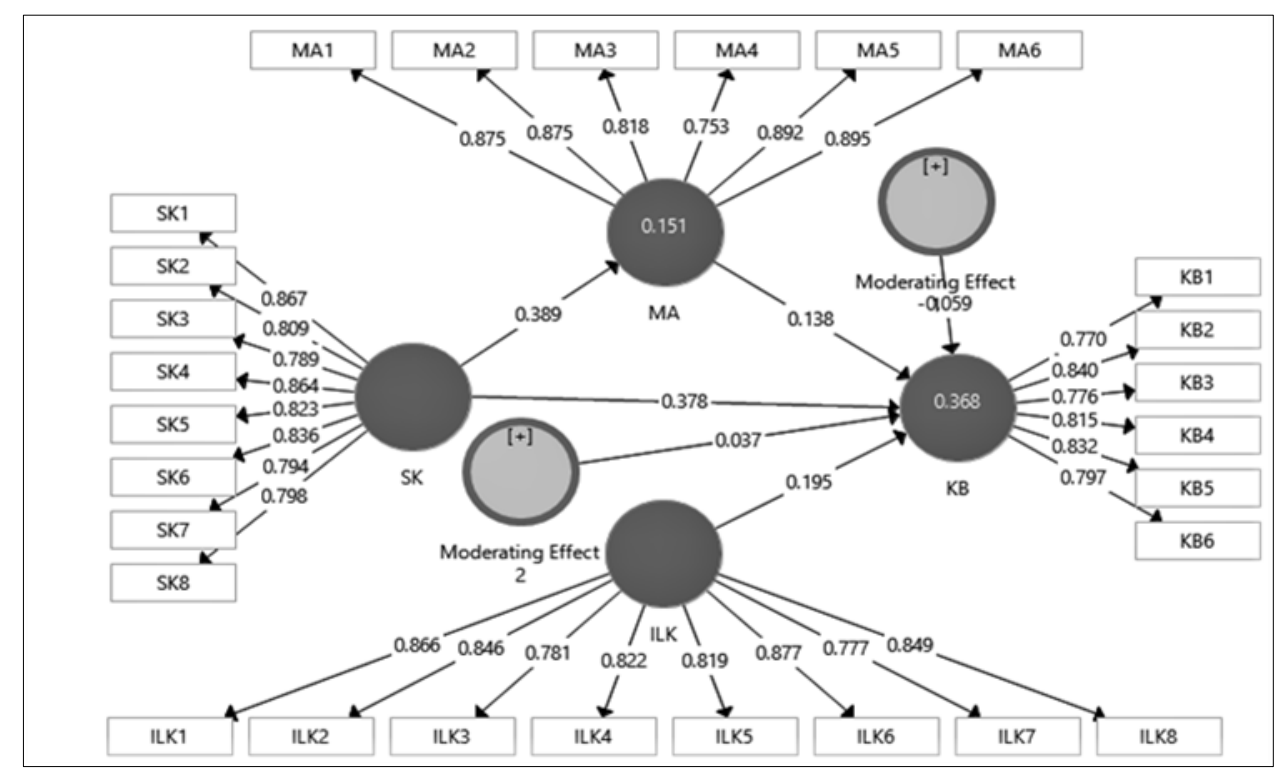

Figure 2 Value of Loading Factor

Another manner to validate the difference is to test the rectangular root of the suggest variance extraction (AVE) value. The recommended value is extra than 0.5. The AVE values for this look at are:

Table 3 Average Variance Extracted (AVE)

\begin{tabular}{|l|c|}
\hline & Average Variance Extracted (AVE) \\
\hline ILK & 0.690 \\
\hline KB & 0.649 \\
\hline MA & 0.728 \\
\hline Moderating Effect 1 & 1.000 \\
\hline Moderating Effect 2 & 1.000 \\
\hline SK & 0.677 \\
\hline
\end{tabular}


The desk above suggests the AVE values above 0.5 for all variables used within side the take a look at model. The minimal AVE price for the KB variable (Competitive Advantage) is 0.649 .

\subsubsection{Reliability Test}

The reliability check examines the reliability value of the composite indicator block used to calculate the variable. If the combined reliability is extra than 0.7 . the end result is acceptable. The combined confidence value is as follows:

Table 4 Composite Reliability

\begin{tabular}{|l|c|}
\hline & Composite Reliability \\
\hline ILK & 0.947 \\
\hline KB & 0.917 \\
\hline MA & 0.941 \\
\hline Moderating Effect 1 & 1.000 \\
\hline Moderating Effect 2 & 1.000 \\
\hline SK & 0.944 \\
\hline
\end{tabular}

The cumulative reliability score for all variables within side the desk greater than 0.7 . indicating that everyone variables within side the calculated model meets the discriminant validity requirements. The lowest composite reliability value is 0.917 for the KB variable (Competitive Advantage).

Cronbach's Alpha. with Smart PLS-3 overall performance providing can additionally be used to enhance reliability testing

Table 5 Cronbach's Alpha

\begin{tabular}{|l|c|}
\hline & Cronbach's Alpha \\
\hline ILK & 0.935 \\
\hline KB & 0.892 \\
\hline MA & 0.924 \\
\hline Moderating Effect 1 & 1.000 \\
\hline Moderating Effect 2 & 1.000 \\
\hline SK & 0.932 \\
\hline
\end{tabular}

Recommended values are more than 0.6. and the desk above indicates that everyone Cronbach's Alpha variables have values more than 0.6. For the variable KB (Competitive Advantage) the minimal value is 0.892.

\subsection{Structural Model Testing}

The structural model is tested after the anticipated model follows the specifications for the Outer Model. The R-Square value of the variable is as follows:

Table 6 R-Square

\begin{tabular}{|c|c|}
\hline & R Square \\
\hline KB & 0.368 \\
\hline MA & 0.151 \\
\hline
\end{tabular}


In the table above. the value of the variable KB (Competitive Advantage) is 0.368. This means that SK (Partnership Strategy). MA (Market Area). and ILK (Health Service Innovation) can explain $36.8 \%$ of the relationship with the variable KB. Similarly. the value of variable MA (Market Area) is 0.151 . This means that SK (Partnership Strategy) can explain $15.1 \%$ of the relationship with the variable SK.

The hypothesis test proceeds as follows:

Table 7 Path Coefficient

\begin{tabular}{|c|c|c|c|c|c|}
\hline & $\begin{array}{c}\text { Original } \\
\text { Sample } \\
\text { (0) }\end{array}$ & $\begin{array}{c}\text { Sample } \\
\text { Mean (M) }\end{array}$ & $\begin{array}{c}\text { Standard } \\
\text { Deviation } \\
\text { (STDEV) }\end{array}$ & $\begin{array}{c}\text { T Statistics } \\
\text { (|O/STDEV|) }\end{array}$ & $\begin{array}{c}\text { P } \\
\text { Values }\end{array}$ \\
\hline SK -> KB & 0.378 & 0.377 & 0.102 & 3.691 & 0.000 \\
\hline SK -> MA -> KB & 0.054 & 0.048 & 0.057 & 0.949 & 0.343 \\
\hline ME 1(MA - - KB) & -0.059 & -0.053 & 0.122 & 0.481 & 0.631 \\
\hline ME 2(SK -> KB) & 0.037 & 0.047 & 0.099 & 0.369 & 0.712 \\
\hline ILK -> KB & 0.195 & 0.205 & 0.089 & 2.188 & 0.029 \\
\hline SK -> MA & 0.389 & 0.394 & 0.085 & 4.567 & 0.000 \\
\hline MA -> KB & 0.138 & 0.119 & 0.135 & 1.024 & 0.307 \\
\hline
\end{tabular}

The effect of the Partnership Strategy (SK) on Competitive Advantage (KB) is very good or significant with a P value of $0.000(<0.05)$. The positive estimation value is 0.378 which indicates that the relationship between the Partnership Strategy (SK) and Competitive Advantage (KB) is good. Thus. the H1 assumption of this review which states that the Partnership Strategy (SK) has an effect on Competitive Advantage (KB) is accepted.

There is an insignificant effect of mediation with the help of the use of Market Area (MA) on the Partnership Strategy (SK) and Competitive Advantage (KB) resulting in P Values of $0.343(>0.05)$. Thus. H2's assumption regarding this matter which states that the Partnership Strategy (SK) has an impact on Competitive Advantage (KB) through the Market Area (MA) is rejected.

Health Service Innovation (ILK) cannot moderate the Market Area (MA) on Competitive Advantage (KB) which has P Values of 0.631 (>0.05) and Partnership Strategy (SK) on Competitive Advantage (KB) has P Values of 0.712 ( $>0.05$ ). Thus. the assumption $\mathrm{H} 3$ in this review which states that Health Service Innovation (ILK) can moderate the Partnership Strategy (SK) and Market Area (MA) on Competitive Advantage (KB) is rejected. Because the relationship between Health Service Innovation (ILK) and Competitive Advantage (KB) is significant with a P value of $0.029(<0.05)$. then Health Service Innovation (ILK) can be said to function or act as a moderating predictor.

\section{Discussion}

Competitive advantage is an elaboration of the reality of management which is a process to identify. develop and put a real advantage. All company resources that support competitive advantage are often used as research to be used as the basis for strategies that will be applied in company management [24]. Day and Wensley [25] stated that the basic unification of competitive advantage from the capabilities and resources of the organization is a determining factor of position and relatively better performance compared to competitors. Activities from the company's performance in particular will be the basis for building sources that have a competitive advantage.

Competitive advantage will build the ability and performance of activities that are more than competitors or more effective than competitors. In other words. companies build competitive advantage when utilizing strengths for some activities more than their performance [4]. A company occupies a position of competitive advantage is due to a comparative advantage in resources resulting in superior value at lower costs. Competitive advantage in health facilities cannot be understood only by looking at it as a company. Competitive advantage comes from the many different activities carried out by companies in this case hospitals to design. manufacture. market. provide and support excellent health services. 
A competitive strategy in healthcare aims to establish a favorable and defensible position against the forces that determine competition in the healthcare sector. The ultimate goal is to overcome problems in terms of providing medical services and can also change the existing system or regulation. for the better.

The next competitive strategy that can be used is to provide complete and more complete and attractive products. facilities and atmosphere that are designed in such a way. taking into account social. cultural. economic and site selection aspects. With the determination of a competitive advantage strategy through service innovation and market area. it is expected to be able to compete with superior competitors. including in providing the best health services between health facilities. both hospitals and health centers.

\section{Conclusion}

This have a take a observe proposes a version of partnership strategy variables on competitive advantage the usage of the market area as a mediating variable and health service innovation as a moderating variable that has now not been extensively studied. The results show that the partnership strategy has a direct effect on competitive advantage. The partnership strategy has a direct effect on the market area. but the market area cannot mediate the relationship between the partnership strategy and competitive advantage. Health service innovation has a direct effect on competitive advantage. but health service innovation cannot moderate relationship between partnership strategy and competitive advantage and cannot moderate relationship between market area and competitive advantage. While the market area has no direct significant effect on competitive advantage.

\section{Compliance with ethical standards}

\section{Acknowledgments}

The author would like to thank Rumkital Management dr. F.X. Suhardjo Lantamal IX Ambon.

\section{Disclosure of conflict of interest}

The Author wish to declare that none has any interest to disclose.

\section{References}

[1] K Lee. M Madanoglu. J-Y Ko. Developing a competitive international service strategy: a case of international joint venture in the global service industry. J. Serv. Mark.. 2013.

[2] P Haynes. M Allen. Partnership as union strategy: a preliminary evaluation. Empl. Relations. 2001.

[3] K Urabe. Innovation and the Japanese management system. Innov. Manag. Int. Comp. Berlin Walter Gruyter. 1988.

[4] MS Poole. AH Van de Ven. Handbook of organizational change and innovation. Oxford University Press. 2004.

[5] GLH Prasetya. E Rahardja. R Hidayati. Membangun Keunggulan Kompetitif melalui Aliansi Stratejik untuk Meningkatkan Kinerja Perusahaan (Studi Kasus pada PT. POS Indonesia Wilayah VI Jateng dan DIY). J. Stud. Manaj. Organ. 2007; 4(2): 1-19.

[6] D Campbell. D Edgar. G Stonehouse. Business strategy: an introduction. Macmillan International Higher Education. 2011.

[7] P Dussauge. B Garrette. Determinants of success in international strategic alliances: Evidence from the global aerospace industry. J. Int. Bus. Stud. 1995; 26(3): 505-530.

[8] Y Doz. G Hamel. CK Prahalad. Collaborate with your competitors and win. Harv. Bus. Rev. 1989; 67(1): 133-139.

[9] J Bleeke. D Ernst. The way to win in cross-border alliances.. Harv. Bus. Rev. 1991; 69(6): 127-135.

[10] T Ariefiantoro. peran inovasi dan kemitraan dalam meningkatkan keunggulan bersaing umkm batik semarangan. 2015.

[11] DJ Winata. Analisa Pengaruh Aliansi Stratejik Terhadap Keunggulan Bersaing dan Kinerja Perusahaan. Bus. Account. Rev. 2013; 1(2): 216-225.

[12] NNK Yasa. Peran partnership strategy untuk meningkatkan kinerja perusahaan (Studi pada bank perkreditan rakyat di Provinsi Bali). EKUITAS (Jurnal Ekon. dan Keuangan). 2010; 14(3): 305-329. 
[13] JP Guiltinan. GW Paul. TJ Madden. Marketing management: Strategies and programs. McGraw-Hill/Irwin. 1997.

[14] DW Cravens. Implementation strategies in the market-driven strategy era. J. Acad. Mark. Sci. 1998; 26(3): 237241.

[15] P Kotler. Manajemen Pemasaran. edisi kesebelas. Jakarta Indeks kelompok Gramedia. 2003.

[16] A Weber. Theory of Location of Industries. Chicago. Friedrich Carl J. Chicago Illinois. University of Chicago Press. 1909.

[17] H Mintzberg. Tracking strategies: Toward a general theory. OUP Oxford. 2007.

[18] F Indriani. Aliansi Strategis dan Pengembangan Produk. J. Stud. Manaj. dan Organ. 2005; 2(1): 111-119.

[19] A Ferdinand. Structural equation modeling dalam penelitian manajemen: aplikasi model-model rumit dalam penelitian untuk Tesis Magister \& Disertasi Doktor. Language (Baltim). 2005; 3 390. 24cm.

[20] C Dröge. S Vickery. RE Markland. Sources and outcomes of competitive advantage: an exploratory study in the furniture industry. Decis. Sci. 1994; 25(5-6): 669-689.

[21] RM Monczka. KJ Petersen. RB Handfield. GL Ragatz. Success factors in strategic supplier alliances: the buying company perspective. Decis. Sci. 1998; 29(3): 553-577.

[22] Sugiyono. Metode penelitian kombinasi (mixed methods). Bandung Alf. 2015; 28.

[23] P. D. Sugiyono. Metode Penelitian Kuantitatif Kualitatif Dan R\&D. Bandung: Cv. Alvabeta. 2009.

[24] T. L. Wheelen and J. D. Hunger. Strategic management and business policy: entering 21st century global society. 1998.

[25] G. S. Day and R. Wensley. Assessing advantage: a framework for diagnosing competitive superiority.J. Mark. 1988; 52(2): $1-20$. 